\title{
ANALISIS PENETAPAN PENGADILAN TERHADAP ANAK PELAKU TINDAK PIDANA PENYALAHGUNAAN NARKOTIKA (STUDI KASUS: PENETAPAN PENGADILAN NEGERI SURABAYA DAN 2 (DUA) PUTUSAN PENGADILAN NEGERI JAKARTA BARAT)
}

\author{
Lie Natania \\ (Mahasiswa Program S1 Fakultas Hukum Universitas Tarumanagara) \\ (E-mail: natanialie19@gmail.com)

\section{Dr. Mety Rahmawati, S.H., M.H.} \\ (Corresponding Author) \\ (Dosen Fakultas Hukum Universitas Tarumanagara. Meraih Sarjana Hukum pada Fakultas Hukum \\ Universitas Trisakti, Magister Hukum pada Fakultas Hukum Universitas Tarumanagara, Doktor (Dr.) \\ pada Fakultas Hukum Universitas Trisakti) \\ (E-mail: metyargo@gmail.com)
}

\begin{abstract}
Children are the future of mankind, our nation and country. Based on this strategic position, the state and the law must provide special protection for children. However, in finding themselves, in some occasions children can stumble and make mistakes, which unfortunately can be in the form of run-ins with the law. Act Number 11 of Year 2012 regarding the Criminal Justice System for Juvenile presented the concept of diversion, which is an approach to resolve juvenile cases in order to achieve restorative justice. Diversion is the of process diverting child cases out of the usual system of criminal justice. However, diversion cannot be used to resolve all and every child cases. In a case of drug abuse, as seen in the Verdict of Surabaya District Court Number 111/Pid.Sus-Anak/2014/PN.Sby, diversion is attempted to resolve the case. But in two similar cases, namely in the Verdict of West Jakarta District Court Number 47/Pid.Sus-Anak/2017/PN.Jkt.Brt and Number 53/Pid.SusAnak/2017/PN.Jkt.Brt, diversion was not attempted resolve the children in those cases and as stated on the verdict, those children were convicted. Why is there a difference in the resolution of the court against children who committed drug abuse between the Verdict of Surabaya District Court Number 111/Pid.Sus-Anak/2014/PN.Sby, the Verdict of West Jakarta District Court Number 47/Pid.SusAnak/2017/PN.Jkt.Brt and the Verdict of West Jakarta District Court Number 53/Pid.SusAnak/2017/PN.Jkt.Brt?
\end{abstract}

Keywords: child, juvenile criminal justice system, diversion, drug abuse 


\section{PENDAHULUAN}

\section{A. Latar Belakang}

Anak merupakan generasi pelanjut keberlangsungan hidup manusia, termasuk juga dalam bangsa dan negara Indonesia. Berdasarkan posisi yang strategis demikian, Pasa1 28 B Ayat (2) peraturan perundang-undangan dasar kita, yaitu Repubik Indonesia pada Tahun 1945 (UUD 1945) mengatur bahwa perlu dijaminnya hak dan perlindungan terkait hak konstitusional anak yang pada intinya mengatakan bahwa setiap anak berhak atas perlindungan dari segala bentuk diskriminasi dan kekerasan, dan juga atas keberlangsungan hidup, tumbuh, dan berkembang.

Menurut Kamus Besar Bahasa Indonesia (KBBI), anak adalah keturunan yang kedua. ${ }^{1)}$ Dalam pertimbangan pembuatan peraturan perundang-undangan Nomor 23 pada Tahun 2002 mengenai Perlindungan bagi Anak, dinyatakan bahwa anak itu ialah keturunan dan juga karunia dari Tuhan YME, yang pada dirinya sudah terlekat martabat dan juga harkat sebagai manusia sepenuhnya.

Sesuai dengan sebutannya itu, anak adalah manusia yang masih dalam proses tumbuh kembang. Anak, dengan demikian masih sangat perlu orang lain, terutama orang tua dan masyarakat, untuk menjaga dan memandu dalam proses tumbuh kembang tersebut, agar kelak anak dapat menjadi seorang yang dewasa yang dapat memikul tanggung jawab, termasuk dalam menjalani hak dan kewajibannya dalam kehidupannya di dalam hidup bermasyarakat, dalam bangsa, maupun negara.

Agar anak pada waktu kemudian dapat menjalani tanggung jawab tersebut, maka anak wajib mendapatkan kesempatan yang seluas luasnya untuk tumbuh dan berkembang secara maksimal, baik secara fisik (physically), mental (mentally) maupun sosial (socially). Untuk mencapai hal tersebut dan untuk mewujudkan kesejahteraan anak, maka perlu dilakukan

\footnotetext{
1) Anonim, "Pengertian Anak", https://kbbi.web.id/anak, diakses tanggal 25 Mei 2018.
} 
upaya perlindungan dengan memberikan jaminan terhadap pemenuhan hakhaknya serta adanya perlakuan tanpa bentuk diskriminasi apapun juga. ${ }^{2)}$

Dalam proses tumbuh kembang, setiap anak tidak luput dari membuat kesalahan, dan dalam menghadapi permasalahannya, kadangkala anak dapat melakukan penyimpangan atau bahkan tindakan melanggar hukum. Keterbatasan anak dalam mengerti dan melindungi dirinya sendiri dari pengaruh pengaruh yang ada juga menjadi salah satu penyebab terjadinya penyimpangan atau pelanggaran hukum yang dilakukan oleh anak. Oleh karena itu, apabila anak menjadi pelaku tindak pidana, negara dan hukum harus memberikan perlindungan kepadanya. ${ }^{3)}$

Anak karena masih dalam proses tumbuh-kembang, tidak memiliki kematangan jiwa untuk dapat memikul tanggung jawab layaknya seorang manusia dewasa, dan oleh sebab itu harus ada pandangan yang tepat ketika anak melakukan penyimpangan atau pelanggaran hukum. Dengan adanya pandangan seperti itu, maka tampak jelas bahwa perlu adanya perlakuan dan sikap yang tepat pula dalam menangani kasus anak. Hal ini dikarenakan bahwa umumnya, tindak pidana atau pelanggaran hukum yang dibuat anak tidaklah berasal dari motive yang jahat (evil mind / evil will), melainkan karena kenakalan anak atau istilah Juvenile Delinquency, sehingga anak tidak dapat digolongkan atau dikategorikan sebagai penjahat (criminal). ${ }^{4)}$

Perlindungan bagi anak yang di duga telah memperbuat suatu bentuk pelanggaran hukum atau tindak pidana biasanya memiliki sifat yang sangat represif atau dalam kata lain sangat mengekang atau menindas bagi anak. Proses peradilan pidana bagi anak kerap kali kehilangan hakikatnya sebagai suatu mekanisme yang harus berakhir dengan upaya untuk melindungi the

\footnotetext{
${ }^{2)}$ M. Nasir Djamil, Anak Bukan Untuk Dihukum (Jakarta: Sinar Grafika, 2013), 2.

3) Marlina, Peradilan Pidana Anak Di Indonesia: Pengembangan Konsep Diversi dan Restorative Justice (Bandung: Refika Aditama, 2012), xv.

4) Nandang Sambas, Peradilan Pidana Anak di Indonesia dan Instrumen Internasional Perlindungan Anak serta Penerapannya (Yogyakarta: Graha Ilmu, 2013), 13.
} 
best interest of child (kepentingan terbaik bagi anak). Proses peradilan pidana bagi anak kerap kali menampakkan diri sebagai suatu proses yang lebih berorientasi pada penegakan hukum secara formil dibanding berorientasi pada kepentingan terbaik bagi anak. ${ }^{5)}$

Penyelesaian perkara bagi anak yang memiliki konflik dengan hukum (anak yang berkonflik dengan hukum) idealnya harus mengutamakan prinsipprisnip hak anak yang tujuan utamanya adalah untuk melindungi haknya anak, di mana penangkapan, penahanan, atau bahkan penjara hanya dilakukan sebagai upaya terakhir (ultimum remedium) dan dalam jangka waktu yang sesingkat-singkatnya. ${ }^{6)}$

Lahirnya peraturan perundang-undangan Nomor 23 pada Tahun 2002 tentang Perlindungan Anak sebagaimana telah di ubah dengan peraturan perundang-undangan Nomor 35 Tahun 2014 (selanjutnya disebut sebagai "UU P.A.") dan peraturan perundang-undangan Nomor 11 Tahun 2012 mengenai Sistem Peradilan Pidana Anak (selanjutnya disebut sebagai "UU S.P.P.A.”) memberi warna berbeda terkait perlindungan hukum bagi anak di Republik Indonesia. UU S.P.P.A. melahirkan konsep diversi yang tujuannya adalah untuk memberi perlindungan terhadap pelaku kejahatan, korban dan masyarakat pada umumnya sebagai suatu bentuk untuk menyelesaikan perkara. Berdasarkan Pasa1 1 Angka 7 UU S.P.P.A., diversi adalah pengalihan penyelesaian perkara anak dari proses peradilan pidana ke proses di luar peradilan pidana.

Konsep diversi lahir dari pemikiran bahwa tidak seluruh kasus anak yang berhadapan atau berkonflik dengan hukum harus melewati jalur peradilan pidana formil, dan memberikan sebuah penyelesaian alterative yaitu dengan pendekatan restorative justice atau keadilan restoratif. Maka, terhadap perkara

5) Suhadi, "Urgensi Undang-Undang Sistem Peradilan Pidana Anak", Jurnal Hukum Khaira Ummah, Volume 12. Nomor 4 (Desember 2017): 855.

${ }^{6)}$ M. Nasir Djamil, Op. Cit., 58. 
anak-anak yang berkonflik dengan hukum dapat diupayakan diversi demi kepentingan terbaik anak namun juga tetap mempertimbangkan keadilan bagi korban. ${ }^{7)}$ Hal ini juga bertujuan untuk menghindari stigma jahat pada anak.

Diversi merupakan konsep yang berorientasi pada kepentingan terbaik bagi anak, karena tujuannya adalah untuk mencapai keadaan damai antara anak dan korban, menyelesaikan kasus anak di luar proses peradilan pidana, menjauhkan anak dari segala bentuk perampasan kemerdekaan, mendorong masyarakat untuk turut berpartisipasi dan juga menanamkan rasa tanggung jawab kepada anak tersebut. ${ }^{8)}$ Oleh sebab itu, pelaksanaannya sangatlah penting.

Sebagaimana diatur dalam Pasa1 7 UU S.P.P.A., diversi wajib diupayakan pada semua tingkat pemeriksaan, termasuk di dalamnya penyidikan, penuntutan dan pemeriksaan perkara di pengadilan negeri, dan wajib dilaksanakan bagi tindak pidana yang dilakukan diancam dengan pidana penjara di bawah 7 (tujuh) tahun dan anak belum pernah melakukan tindak pidana sebelumnya.

Kemudian, dalam Pasa1 3 Peraturan Mahkamah Agung Republik Indonesia Nomor 4 pada Tahun 2014 tentang Pedoman Pelaksanaan Diversi dalam Sistem Peradilan Pidana Anak (selanjutnya disebut sebagai "Perma 4/2014”), hakim Anak wajib mengupayakan diversi bagi anak yang didakwa dengan tindak pidana dengan ancaman pidana penjara di bawah 7 (tujuh) tahun maupun bagi anak didakwa pula dengan tindak pidana dengan ancaman pidana penjara 7 (tujuh) tahun atau lebih dalam bentuk surat dakwaan subsidiaritas, alternatif, kumulatif maupun kombinasi (gabungan).

Namun dalam beberapa putusan mengenai tindak pidana penyalahgunaan narkotika, ternyata Pasa1 atau norma tersebut tidak dilaksanakan secara konsisten, seperti yang terjadi di Jawa Timur dan di Jakarta. Pertama-tama,

\footnotetext{
${ }^{7)}$ Ibid., 137.

${ }^{8)}$ Ibid., 138.
} 
dalam Penetapan Pengadilan Negeri Surabaya Nomor 111 / Pid.Sus-Anak / 2014 / PN.Sby, Penulis menemukan bahwa anak yang berkonflik dengan hukum bernama Jerrico Rizky Anugrah bin Heri Siswanto (17) diancam dengan Pasa1 112 Ayat (1) dalam peraturan perundang-undangan Nomor 35 pada Tahun 2009 tentang Narkotika (selanjutnya disebut sebagai "UU Narkotika"), dengan ancaman pidana paling lama 12 (dua belas) tahun. Namun, sebagaimana dapat disimpulkan dari penetapan tersebut, diversi diupayakan (yang dibuktikan dengan adanya Berita Acara Diversi Nomor 111 / Pid.Sus-Anak / 2014 / PN.Sby, tanggal 18 November 2014) dan berhasil. Sehingga, anak tidak dihukum pidana.

Sedangkan, dalam Putusan Pengadilan Negeri Jakarta Barat Nomor 47 / Pid.Sus-Anak / 2017 / PN.Jkt.Brt., pengadilan tersebut memeriksa dan mengadili Endeng Rafli Adillah bin Askar Suseno (17) atas dakwaan yang sama, yaitu Pasal 112 Ayat (1) jo. Pasal 132 Ayat (1) UU Narkotika. Di mana dalam putusan ini, tidak terdapat bukti bahwa telah diupayakan diversi, walau pada kenyataannya kedua anak tersebut didakwa dengan Pasa1 yang sama. Alhasil, pengadilan mengadili menjatuhkan pidana penjara kepada Endeng Rafli Adillah bin Askar Suseno (17) selama 1 (satu) tahun dan pidana tambahan berupa pelatihan kerja selama 1 (satu) bulan.

Kemudian, dalam Putusan Pengadilan Negeri Jakarta Barat Nomor 53 / Pid.Sus-Anak / 2017 / PN.Jkt.Brt., anak yang berkonflik dengan hukum Ahmad Suryadi bin Maddin Rangkuti (16) didakwa dengan Pasa1 yang sama pula, yaitu Pasa1 112 Ayat (1) UU Narkotika. Dan dalam putusan tersebut, juga tidak ditemukan bukti bahwa telah diupayan diversi. Berbeda lagi dari putusan sebelumnya, pengadilan mengadili menjatuhkan pidana penjara kepada Ahmad Suryadi bin Maddin Rangkuti (16) selama 2 (dua) tahun dan denda sebesar Rp.800.000.000,- (delapan ratus juta rupiah).

Melihat fakta-fakta tersebut, jelas terdapat 3 (tiga) penetapan / putusan yang berbeda atas 3 (tiga) kasus yang sama. Meskipun diadili oleh pengadilan 
yang berbeda, akan tetapi karena yang dijadikan dasar acuan sama, yaitu UU S.P.P.A., maka seharusnya putusannya sama. Sehingga patut dipertanyakan yang mana yang benar dari ketiga putusan tersebut, karena putusan yang berbeda-beda tersebut dapat menimbulkan ketidakpastian hukum dan merugikan terhadap kepentingan anak. Oleh sebab itu, Penulis sangat tertarik untuk melakukan penelitian guna mencari tahu tentang permasalahan ini lebih lanjut.

Bertitik tolak dari pemikiran yang dikemukakan di atas, maka Penulis tertarik untuk mengkaji permasalahan ini dalam bentuk tulisan berupa skripsi dengan judul "Analisis Penetapan Pengadilan Terhadap Anak Pelaku Tindak Pidana Penyalahgunaan Narkotika (Studi Kasus: Penetapan Pengadilan Negeri Surabaya Nomor 111 / Pid.Sus-Anak / 2014 / PN.Sby, Putusan Pengadilan Negeri Jakarta Barat Nomor 47 / Pid.Sus-Anak / 2017 / PN.Jkt.Brt dan Putusan Pengadilan Negeri Jakarta Barat Nomor 53 / Pid.Sus-Anak / 2017 / PN.Jkt.Brt)".

\section{B. Permasalahan}

Melihat latar belakang sebagaimana terpapar di atas, maka Penulis merumuskan permasalahan sebagai berikut yaitu: Mengapa terdapat perbedaan penetapan pengadilan terhadap anak pelaku tindak pidana penyalahgunaan narkotika dalam Penetapan Pengadilan Negeri Surabaya Nomor 111 / Pid.SusAnak / 2014 / PN.Sby, Putusan Pengadilan Negeri Jakarta Barat Nomor 47 / Pid.Sus-Anak / 2017 / PN.Jkt.Brt dan Putusan Pengadilan Negeri Jakarta Barat Nomor 53 / Pid.Sus-Anak / 2017 / PN.Jkt.Brt?

\section{PEMBAHASAN}

A. Analisis Penetapan Pengadilan Terhadap Anak Pelaku Tindak Pidana Penyalahgunaan Narkotika dalam Penetapan Pengadilan Negeri Surabaya Nomor 111 / Pid.Sus-Anak / 2014 / PN.Sby, Putusan Pengadilan Negeri Jakarta Barat Nomor 47 / Pid.Sus-Anak / 2017 / PN.Jkt.Brt dan Putusan 


\section{Pengadilan Negeri Jakarta Barat Nomor 53 / Pid.Sus-Anak / 2017 / PN.Jkt.Brt}

Dalam penelitian ini, Penulis melakukan analisis dan perbandingan terhadap 3 (tiga) kasus penyalahgunaan narkotika oleh anak yang serupa dengan 3 (tiga) penetapan / putusan berbeda. Pertama-tama dalam Penetapan Pengadilan Negeri Surabaya Nomor 111 / Pid.Sus-Anak / 2014 / PN.Sby, dengan anak yang berkonflik dengan hukum bernama Jerrico Rizky Anugrah bin Heri Siswanto, umur 17 tahun.

Jerrico Rizky Anugrah diancam dengan Pasa1 112 Ayat (1) UU Narkotika yang isinya adalah tiap orang yang tanpa hak atau melawan hukum memiliki, menyimpan, menguasai, atau menyediakan Narkotika Gol. 1 bukan berbentuk tanaman, dapat dipidana dengan penjara paling cepat 4 (empat) tahun dan paling lama 12 (dua belas) tahun dan denda minimal Rp 800.000.000,00 (delapan ratus juta rupiah) dan maksimal Rp 8.000.000.000,00 (delapan miliar rupiah).

Berdasarkan laporan hakim tanggal 18 November 2014 perihal laporan hasil diversi, antara anak dan JPU dan BAPAS telah dicapai kesepakatan diversi dengan kesepakatan sebagai berikut:

1. Jerrico Rizky Anugrah telah mengakui dan menyesali perbuatannya dan berjanji tidak akan lagi mengulangi perbuatannya tersebut;

2. PK (Pembimbing Kemasyarakatan) BAPAS kelas 1 Surabaya menyetujui Assesmen Terpadu BNN Provinsi Jawa Timur yang memberi rekomendasi agar Jerrico Rizky Anugrah menjalani Rehabilitasi Sosial di UPT Rehab Sosial ANKN (Anak Nakal dan Korban Narkotika);

3. JPU dan BAPAS sepakat, bahwa Jerrico Rizky Anugrah akan menjalani Rehabilitasi Sosial di ANKN (Anak Nakal dan Korban Narkotika) selama 4 (empat) bulan. 
Pertimbangan hakim dalam memberikan rehabilitasi bagi Jerrico Rizky Anugrah sebagai anak pelaku tindak pidana penyalahgunaan narkotika pada penetapan ini adalah:

1. Jerrico Rizky Anugrah telah mengakui dan menyesali perbuatannya dan berjanji tidak akan lagi mengulangi perbuatannya tersebut;

2. PK (Pembimbing Kemasyarakatan) BAPAS kelas 1 Surabaya menyetujui Assesmen Terpadu BNN Provinsi Jawa Timur yang memberi rekomendasi agar Jerrico Rizky Anugrah menjalani Rehabilitasi Sosial di UPT Rehab Sosial ANKN (Anak Nakal dan Korban Narkotika);

3. BNN telah memberi asesmen bahwa anak tersebut akan menjalani rehabilitasi sosial selama 4 (empat) bulan.

Dalam kasus ini, Ketua Pengadilan Negeri Surabaya menetapkan Penetapan Diversi, yang isinya memerintahkan para pihak untuk melaksanakan kesepakatan diversi yaitu anak, Jerrico Rizky Anugrah, harus menjalani Rehabilitasi Sosial di ANKN (Anak Nakal dan Korban Narkotika) selama 4 (empat) bulan dan setelah kesepakatan diversi dilaksanakan seluruhnya, memerintahkan hakim untuk mengeluarkan penetapan penghentian pemeriksaan.

Kemudian, dalam Putusan Pengadilan Negeri Jakarta Barat Nomor 47 / Pid.Sus-Anak / 2017 / PN.Jkt.Brt., dengan anak Endeng Rafli Adillah bin Askar Suseno, umur 17 tahun. Endeng Rafli Adillah bin Askar Suseno pada hari Rabu tanggal 1 November 2017 kurang lebih Pukul 11:00 W.I.B. atau pada waktu lain dalam bulan November tahun 2017 di Jl. Krendang Timur I Rt.004/001 Kel. Krendang Kec. Tambora Jakarta Barat, atau di tempat lain yang setidaknya dalam daerah hukum Pengadilan Negeri Jakarta Barat, tanpa hak atau melawan hukum memiliki, menyimpan, menguasai atau menyediakan Narkotika Gol. 1 bukan berbentuk tanaman sebagaimana diatur dan diancam pidana dalam Pasal 112 Ayat (1) jo. Pasal 132 Ayat (1) UU Narkotika. 
Endeng Rafli Adillah bin Askar Suseno (Anak), Endeng Rudini bin Askar Suseno, dan Irpan bin Syafarudin (keduanya sebagai terdakwa dalam berkas perkara terpisah) pada saat penggeledahan kedapatan menyimpan Narkotika jenis shabu sebanyak 1 (satu) paket plastic kecil yang disimpan di kantong celana depan sebelah kanan, yang menurut Endeng Rudini bin Askar Suseno bahwa shabu tersebut adalah milik beberapa orang yang dibeli secara iuran atau patungan seharga Rp 150.000,- (seratus lima puluh ribu rupiah) dengan menggunakan uang Anak Endeng Rafli Adillah bin Askar Suseno, uang Endeng Rudini bin Askar Suseno dan uang Irpan bin Syafarudin per orang sejumlah Rp 50.000,- (lima puiuh ribu rupiah).

Sebelum menjatuhkan pidana terhadap Endeng Rudini, hakim mempertimbangkan beberapa hal yang memberatkan dan meringankan anak, yaitu sebagai berikut:

Hal hal yang memberatkan: Perbuatan Endeng Rudini bertentangan dengan program pemerintah dalam upaya pemberantasan Narkoba;

Hal hal yang meringankan: Endeng Rudini menyesal dan mengakui perbuatannya, serta berjanji tidak akan mengulangi perbuatannya.

Terhadap perkara tersebut, Pengadilan Negeri Jakarta Barat menjatuhkan pidana terhadap Anak Endeng Rafli Adillah bin Askar Suseno dengan pidana pembinaan pada Lembaga Pembinaan Khusus Anak (LPKA) Salemba dengan penjara selama 1 (satu) Tahun dan pelatihan kerja selama selama 1 (satu) Bulan di BAPAS Kelas I Jakarta Barat.

Selanjutnya, dalam Putusan Pengadilan Negeri Jakarta Barat Nomor 53 / Pid.Sus-Anak / 2017 / PN.Jkt.Brt., dengan anak yang berkonflik dengan hukum Ahmad Suryadi bin Maddin Rangkuti, umur 16 tahun. Ahmad Suryadi bin Maddin Rangkuti pada hari Senin tanggal 27 November 2017 kurang lebih Pukul 23:30 W.I.B. atau setidaknya pada suatu waktu dalam bulan November 2017 bertempat di Jl. Kebon 200 Rt.003/006 Kel. Kamal Kec. Kalideres Jakarta Barat atau sekiranya pada suatu tempat yang masih 
termasuk dalam wilayah hukum Pengadilan Negeri Jakarta Barat, tanpa hak atau melawan hukum memiliki, menyimpan, menguasai, atau menyediakan Narkotika Gol. 1 yang bukan berbentuk tanaman yang diatur dan diancam pidana dalam Pasa1 112 Ayat (1) UU Narkotika.

Ahmad Suryadi saat penggeledahan tertangkap dengan 1 (satu) bungkus plastic clip berisi narkoba jenis shabu-shabu yang disimpan di bagian belakang baterai handphone merek Samsung yang ada di dalam saku celana depan sebelah kiri. Bahwa sabu tersebut adalah milik Ahamd Suryadi yang dibeli dari Perdi dengan harga Rp 150.000,- (seratus lima puluh ribu rupiah). Akhirnya Ahmad Suryadi langsung ditangkap dan dibawa ke Polsek Kalideres untuk diproses lebih lanjut.

Sebelum hakim menjatuhkan pidana kepada Anak, terlebih dahulu mempertimbangkan beberapa hal yang memberatkan dan yang meringankan hukuman Anak sebagai berikut:

Keadaan yang memberatkan: Perbuatan Ahmad Suryadi tidak mendukung program pemerintah dalam upaya pemberantasan tindak pidana Narkotika;

Keadaan yang meringankan: Ahmad Suryadi belum pernah dihukum, ia juga bersikap sopan di persidangan, ia mengakui dan menyesali perbuatannya dan berjanji tidak akan mengulanginya, Anak masih duduk dibangku sekolah dan berjanji tidak akan mengulanginya lagi.

Putusan hakim dalam perkara tersebut adalah menjatuhkan pidana terhadap Anak tersebut di atas oleh karena itu dengan pidana penjara selama 2 (dua) tahun dan denda sebesar Rp.800.000.000,- (delapan ratus juta rupiah), yang apabila tidak dibayar dapat diganti dengan pidana penjara selama: 1 (satu) bulan.

Sebagaimana kita ketahui, anak adalah bagian yang tidak bisa dipisahkan dari kelangsungan hidup manusia dan juga kelangsungan bagi bangsa dan negara. Sehubungan dengan kedudukannya yang strategis dalam kehidupan bangsa, negara dan manusia pada umumnya, maka anak memerlukan 
perlakuan yang spesial atau khusus, agar dapat tumbuh dan berkembang secara optimal baik dalam bentuk fisik, mental maupun rohani. Maka dari itu anak perlu dijauhkan dari perbuatan-perbuatan pidana atau pelanggaranpelanggaran yang dapat mempengaruhi perkembangan fisik, mental dan rohaninya tersebut secara negatif.

Menghadapi keadaan yang demikian maka hukum harus memeberikan suatu perlindungan khusus kepada anak. Hal ini direalisasikan dengan lahirnya UU P.A. dan kemudian UU S.P.P.A.. Berdasarkan Pasa1 1 Angka 2 UU P.A., perlindungan anak dilakukan untuk melindungi dan menjamin Anak dan hak-haknya agar dapat hidup, tumbuh, berkembang, dan berpartisipasi secara optimal sesuai dengan harkat dan martabat kemanusiaan.

Baik dalam UU P.A. maupun UU S.P.P.A., anak atau anak yang berhadapan dengan hukum khususnya, harus diberikan perlindungan khusus. Perlindungan khusus yang dimaksud dalam Pasal 64 UU P.A. dan Pasa1 4 UU S.P.P.A. antara lain adalah dihindarkan dari penangkapan, penahanan atau penjara, kecuali sebagai ultimum remedium dan dalam waktu yang sesingkatnya.

Dalam penulisan ini, Penulis menganalisa anak pelaku tindak pidana penyalahgunaan narkotika, maka Penulis pun melihat perlindungan khusus bagi anak yang menjadi korban penyalahgunaan narkotika. Berdasarkan Pasa1 67 UU P.A., bagi anak yang menjadi korban penyalahgunaan narkotika dilakukan upaya pengawasan, pencegahan, perawatan dan rehabilitasi.

Apabila UU P.A. mengatur tentang perlindungan khusus bagi anak korban penyalahgunaan narkotika, UU Narkotika juga mengatur mengenai korban penyalagunaan narkotika secara umum. Berdasarkan Pasa1 54 UU Narkotika, korban penyalahgunaan narkotika wajib menjalani rehabilitasi medis dan rehabilitasi sosial.

Selain perlindungan anak sebagaimana disebut diatas, dalam perkembangan ilmu pengetahuan dan perkembangan hukum, muncul teori- 
teori lain, yaitu mengenai teori diversi dan restorative justice. Berdasarkan perkembangan undang-undang perlindungan anak, pada tahun 2012 muncul suatu konsep diversi, berdasarkan UU S.P.P.A.. Diversi dalam UU S.P.P.A. adalah sesuai dengan apa yang dikemukakan oleh Jack E. Bynum tentang sistem diversi, yaitu: Diversion is an endeavor to divert, or to channel out, youtful offenders from the justice system for juveniles.

Prinsip utama pelaksanaan diversi yaitu tindakan persuasif atua pendekatan non-penal untuk memberikan kesempatan bagi seseorang yang melakukan kesalahan untuk memperbaiki kesalahannya. ${ }^{9}$ ) Terutama bagi anak, karena anak dalam melakukan pelanggaran hukum sangat dipengaruhi oleh faktor yang di luar dirinya (faktor eksternal). Untuk memberikan perlindungan bagi anak berupa pengeluaran dari proses formil sistem peradilan pidana, maka timbul pemirkiran manusia atau para ahli hkum untuk membuat suatu peraturan formil tindakan yang dapat mengeluarkan seorang anak yang melakukan pelanggaran hukum atau tindak pidana dari proses peradilan pidana dengan memberikan alternatif lain yang dianggap lebih baik bagi anak.

Hukum mengatur bahwa diversi wajib diupayakan bagi anak yang memenuhi syarat diversi. Syarat diversi dalam PP 65/2015 sama dengan syarat diversi dalam UU S.P.P.A., yaitu diversi diupayakan bagi anak yang diancam dengan pidana penjara dibawah 7 (tujuh) tahun, dan belum pernah berbuat tindak pidana sebelumnya. Sedangkan dalam Perma 4/2014, diatur bahwa diversi wajib diupayakan bagi anak yang diancam pidana penjara dibawah 7 tahun maupun diatas 7 tahun. Perbedaan norma ini akan dibahas lebih lanjut dalam bab ini.

Diversi dilakukan dengan cara musyawarah yang melibat semua pihak, dan berdasarkan pendekatan keadilan restoratif. Teori restorative justice

\footnotetext{
${ }^{9)}$ Marlina, Pengantar Konsep Diversi dan Restorative Justice (Medan: USU Press, 2010), 13.
} 
menurut Muladi yaitu menekankan pada pemulihan atas kerugian yang disebabkan atau terkait dengan tindak pidana yang dilakukan. ${ }^{10)}$

Konsep keadilan restoratif lahir karena sistem peradilan pidana dirasa sangat represif dan kurang memadai kebutuhan baik korban, pelanggar, ataupun anggota masyarakat yang dirugikan. Sehingga dalam proses mencapai keadilan, proses peradilan malah memperdalam luka sosial dan menimbulkan lebih banyak konflik daripada mencapai penyembuhan atau perdamaian. ${ }^{11)}$

Konsep restorative justice meliputi berbagai mekanisme, yang pada dasarnya berpusat dari prinsip dan filosofi yaitu mencari jalur alternatif dalam mencari keadilan saat mengatasi pelanggaran atau kejahatan. Pendekatan restorative justice melihat suatu perbuatan bukan sebagai pelanggaran hukum atau kejahatan, melainkan sebagai kesalahan atau wrongdoing. ${ }^{12)}$

Restorative justice ini memberi jawaban terhadap isu-isu utama dalam sistem peradilan yaitu yang pertama, sistem peradilan tidak memeberi oportunitas khusunya bagi korban, kedua menghilangkan ketegangan antara pelaku, korban dan juga masyarakat, dan yang terakhir adalah untuk mencapai perbaikan akibat dari tindak pidana. ${ }^{13)}$ Konsep ini sejalan dengan tujuan perlindungan anak sebagaimana termaktub dalam UU P.A., yaitu untuk melindungi Anak dan hak-haknya agar dapat hidup, tumbuh, berkembang, dan berpartisipasi secara optimal karena anak merupakan bibit, akar dan generasi penerus cita cita perjuangan bangsa.

Teori diversi dan restorative justice juga sesuai dengan ketentuan perlindungan khusus bagi anak yang berhadapan dengan hukum yaitu

${ }^{10)}$ Yutirsa Yunus, "Analisis Konsep Restorative Justice Melalui Sistem Diversi dalam Sistem Peradilan Pidana Anak di Indonesia”, Jurnal RechtsVinding, Volume 2, Nomor 2 (Agustus 2013): 234.

${ }^{11)}$ Howard Zehr dan Ali Gohar, The Little Book of Restorative Justice (PA: Good Books, 2002), 2 .

${ }^{12)}$ Ibid., 3.

${ }^{13)}$ Kuat Puji Prayitno, "Restorative Justice untuk Peradilan di Indonesia (Perspektif Yuridis Filosofis dalam Penegakan Hukum In Concreto)", Jurnal Dinamika Hukum, Volume 12, Nomor 3 (September 2012): 410. 
penghindaran dari penangkapan, penahanan atau penjara, kecuali sebagai ultimum remedium dan dalam jangka waktu yang paling sesingkat mungkin. Sehingga apabila anak melakukan pelanggaran hukum, dapat terlebih dahulu diupayakan diversi, dalam rangka restorative justice, agar dapat terhindar dari penangkapan, penahanan atau bahkan penjara. Namun, walaupun ada upaya penghindaran dari pemidanaan, anak juga dapat dikenakan sanksi pidana.

Sanksi pidana yang dapat dijatuhkan terhadap anak pun berbeda dengan orang dewasa. Menurut Pasa1 79 UU S.P.P.A., pidana pembatasan kebebasan bagi Anak paling lama 1/2 (setengah) dari maksimum pidana penjara yang diancamkan terhadap orang dewasa, dan khusus untuk pidana penjara bagi anak tidak ada minimumnya.

Bagi anak penyalahguna narkotika, UU Narkotika tidak mengatur khusus untuk itu, sehingga apabila anak menjadi pelaku penyalahgunaan narkotika, tetap mengikuti ketentuan UU Narkotika yang mengatur secara umum baik untuk orang dewasa maupun anak. Pasa1-Pasa1 yang dijatuhkan bagi penyalahguna narkotika biasanya adalah Pasa1 112 atau Pasa1 127 UU Narkotika.

Penyalahguna narkotika diatur secara spesifik dalam Pasa1 127 UU Narkotika, namun dalam praktek, jaksa penuntut umum lebih kerap mendakwa penyalahguna dengan Pasa1 112 UU Narkotika, walaupun antara kedua Pasa1 tersebut memiliki berat ancaman pidana berbeda yang lumayan signifikan. Dalam Pasa1 112 UU Narkotika, diatur bahwa setiap orang yang memiliki, menyimpan, menguasai, atau menyediakan Narkotika Gol. 1 diancam dengan pidana penjara paling singkat 4 (empat) tahun dan paling lama 12 (dua belas tahun), sedangkan dalam Pasa1 127 UU Narkotika, penyalahguna Narkotika Gol. 1 di pidana dengan penjara paling lama 4 (empat) tahun.

Apabila penyalahguna sebagaimana dimaksud dalam Pasa1 127 dapat dibuktikan merupakan korban penyalahguna narkotika, maka ia wajib 
menjalani rehabilitasi medis dan rehabilitasi sosial. Dalam hal anak didakwa dengan Pasa1 112 UU Narkotika, karena anak dianggap pelaku sekaligus korban, maka berdasarkan Pasa1 67 UU P.A., bagi anak yang merupakan korban penyalahgunaan narkotika dilakukan upaya rehabilitasi.

Dalam penelitian ini, Penulis meneliti tentang Anak yang melakukan tindak pidana narkotika, yaitu berupa penyalahgunaan narkotika, dalam arti anak memakai narkotika tanpa hak atau melawan hukum. Hal ini selain merusak diri sendiri, juga dapat merusak lingkungan. Walaupun demikian, negara berdasarkan UU P.A. telah memberikan perlindungan hukum terhadap anak. Semua teori-teori dan peraturan-peraturan yang memberi perlindungan hukum bagi anak terdengar bagus di atas kertas, namun bagaimana dalam prakteknya?

Berdasarkan hasil wawancara, BAPAS setuju dan menerapkan konsep restorative justice dalam menangani kasus anak. Menurut Ludiana, setiap kasus anak yang memenuhi syarat diversi berdasarkan PP 65/2015 akan diupayakan diversi, dan dalam hal kasus anak tidak memenuhi syarat diversi, tetap akan diupayakan "upaya damai" dalam rangka untuk mencapai restorative justice. ${ }^{14)}$

Namun demikian, Penulis berpendapat bahwa sesuai dengan ketentuan Pasa1 81 UU S.P.P.A., karena pidana penjara yang dapat dijatuhkan kepada anak paling lama $1 \frac{1}{2}$ (setengah) dari maksimum ancaman pidana penjara bagi orang dewasa, maka ancaman pidana dalam Pasa1 112 Ayat (1) UU Narkotika dengan ancaman pidana paling lama 12 (dua belas) tahun pun sebenarnya dapat diupayakan diversi karena menjadi 6 tahun.

Hal ini memberi kesan bahwa pihak-pihak yang terkait dalam peradilan anak tidak menguasai peraturan perundang-undangan yang mengatur

14 ) Peneliti, Wawancara, dengan Kepala Subseksi Registrasi Klien Anak di Balai Pemasyarakatan (BAPAS) Kelas 1 Jakarta Barat, (Jakarta: Balai Pemasyarakatan Kelas 1 Jakarta Barat, 30 November 2018). 
mengenai hal itu, sehingga dalam menangani kasus penyalahguna narkotika, tidak diperhatikan bahwa ancaman pidana yang tertera merupakan ancaman maksimal dan bukan ancaman pidana yang dapat dijatuhkan kepada anak.

Upaya damai yang dilakukan baik bagi Endeng Rafly (Putusan Pengadilan Negeri Jakarta Barat Nomor 47 / Pid.Sus-Anak / 2017 / PN.Jkt.Brt) maupun Ahmad Suryadi (Putusan Pengadilan Negeri Jakarta Barat Nomor 53 / Pid.Sus-Anak / 2017 / PN.Jkt.Brt), anak pelaku tindak pidana penyalahgunaan narkotika, adalah membuat rekomendasi dalam Laporan Penelitian Kemasyarakatan berupa pengembalian ke orang tua di bawah bimbingan dan pengawasan BAPAS.

Namun hal ini tidak disetujui oleh hakim di kedua putusan tersebut, karena pengembalian anak yang merupakan penyalahguna narkotika ke orang tua tidak dapat dijamin bahwa anak tersebut tidak akan memakai narkotika lagi. Walaupun dengan adanya bimbingan dan pengawasan BAPAS, namun dengan jumlah kasus yang ditangani oleh BAPAS setiap tahunnya, tidak ada jaminan bahwa anak tersebut tidak akan kembali menjadi penyalahguna. Sehingga pengembalian anak ke orang tua bukanlah suatu solusi yang terbaik.

Kemudian, dalam wawancara dengan Sarjiman, beliau berpendapat bahwa bagi anak penyalahguna narkotika tidak dapat diupayakan diversi, karena menurut beliau untuk dilaksanakan diversi, harus ada korban, dan dalam hal ini, anak dipandang sebagai pelaku sekaligus korban. Sehingga, diversi tidak dapat diupayakan. ${ }^{15)}$ Namun pada kenyataannya, dalam peraturan perundang-undangan yang mengatur tentang diversi, tidak ada ketentuan yang mengatakan demikian. Sebagaimana disebutkan dalam Pasa1 10 UU S.P.P.A., kesepakatan diversi untuk menyelesaikan tindak pidana tanpa korban, tindak pidana ringan, tindak pidana berupa pelanggaran, atau nilai kerugian korban tidak melebihi nilai upah minimum provinsi setempat dapat dilakukan oleh

\footnotetext{
${ }^{15)}$ Peneliti, Wawancara, dengan Hakim Pengadilan Negeri Jakarta Barat, (Jakarta: Pengadilan Negeri Jakarta Barat, 29 November 2018).
} 
penyidik bersama pelaku dan/atau keluarganya, Pembimbing Kemasyarakatan, serta dapat melibatkan tokoh masyarakat. Dari hasil wawancara ini membuktikan bahwa dalam prakteknya, peraturan tidak selalu dijalankan karena hakim mempunyai pendapat/keyakinan sendiri.

Selain itu, perbenturan antara peraturan perundang-undangan juga merupakan suatu masalah dalam pelaksanaan peradilan pidana anak. Seperti halnya dalam Penetapan Nomor 111 / Pid.Sus-Anak / 2014 / PN.Sby, Jerrico Rizky Anugrah yang juga merupakan anak pelaku tindak pidana penyalahgunaan narkotika berhasil diupayakan diversi. Dimana dalam dua putusan Pengadilan Negeri Jakarta Barat, diversi tidak diupayakan bagi anak. Hal ini dikarenakan terdapat ketentuan peraturan perundang-undangan yang tidak konsisten satu dengan lainnya, dimana dalam UU S.P.P.A. dan PP 65/2015 diversi hanya dapat diupayakan bagi anak yang diancam pidana penjara dibawah 7 (tujuh) tahun, sedangkan dalam Perma 4/2014, diversi dapat diupayakan maupun bagi anak yang diancam dengan pidana penjara diatas 7 (tujuh) tahun. ${ }^{16)}$

Dalam Penetapan Nomor 111 / Pid.Sus-Anak / 2014 / PN.Sby dapat dilihat bahwa salah satu hal yang berperan dalam tercapainya kesepakatan diversi adalah bahwa terdapat Asesmen Terpadu BNN yang merekomendasikan agar anak menjalani rehabilitasi sosial. Sehingga hak anak penyalahguna narkotika untuk dilakukan rehabilitasi terpenuhi. Sedangkan dalam Putusan Nomor 47 / Pid.Sus-Anak / 2017 / PN.Jkt.Brt dan Putusan Nomor 53 / Pid.Sus-Anak / 2017 / PN.Jkt.Brt tidak dilaksanakan asesmen yang dibuktikan dari hasil Laporan Penelitian Kemasyarakatan. Disini hak anak sebagai korban penyalahguna narkotika untuk dilakukan rehabilitasi tidak terpenuhi.

16 ) Peneliti, Wawancara, dengan Kepala Subseksi Registrasi Klien Anak di Balai Pemasyarakatan (BAPAS) Kelas 1 Jakarta Barat, (Jakarta: Balai Pemasyarakatan Kelas 1 Jakarta Barat, 30 November 2018). 
Terhadap perbedaan penetapan / putusan dalam kasus-kasus anak ini, Sarjiman berpendapat bahwa hakim dalam membuat suatu penetapan ataupun putusan tidak terikat atau tidak ada kewajiban untuk mengikuti putusan terdahulu, karena hakim memiliki keyakinan sendiri dan kemerdekaan sendiri dalam mempertimbangkan putusan. Kemudian beliau juga mengatakan bahwa dalam melakukan studi kasus, tidak dapat serta merta membandingkan putusan akhir dari hakim, karena setiap kasus itu bersifat kasuistik, tidak bisa digeneralisir. Tidak bisa perkara yang satu disamakan dengan perkara yang lain, harus terlebih dahulu dilihat kasusnya. ${ }^{17)}$

Dalam upaya untuk menjelaskan hal ini, beliau menggunakan analogi sebagai berikut: sama-sama perkara pencurian yang ancaman hukumannya dibawah 7 tahun, tetapi yang satu mencuri sudah direncanakan berhari-hari, yang satu mencuri karena terpaksa harus makan, jadi dari situ akan berbeda penerapan hukumannya.

Oleh sebab itu, guna memberi perbandingan yang jelas terkait kasus yang diteliti, Penulis menuangkan rincian ketiga kasus tersebut ke dalam satu tabel perbandingan.

\begin{tabular}{|l|l|l|l|}
\hline \multirow{5}{*}{} & $\begin{array}{c}\text { Penetapan } \\
\text { Pengadilan } \\
\text { Negeri Surabaya } \\
\text { Nomor 111 / } \\
\text { Pid.Sus-Anak / } \\
2014 \text { / PN.Sby }\end{array}$ & $\begin{array}{c}\text { Putusan Pengadilan } \\
\text { Negeri Jakarta } \\
\text { Barat Nomor 47 / } \\
\text { Pid.Sus-Anak / } \\
2017 \text { / PN.Jkt.Brt }\end{array}$ & $\begin{array}{c}\text { Putusan Pengadilan } \\
\text { Negeri Jakarta } \\
\text { Barat Nomor 53 / } \\
\text { Pid.Sus-Anak / } \\
\text { 2017 / PN.Jkt.Brt. }\end{array}$ \\
\hline \multirow{5}{*}{ Nama Anak } & $\begin{array}{l}\text { Jerrico Rizky } \\
\text { Anugrah bin } \\
\text { Heri Siswanto }\end{array}$ & $\begin{array}{l}\text { Endeng Rafli } \\
\text { Adillah bin Askar } \\
\text { Suseno }\end{array}$ & $\begin{array}{l}\text { Ahmad Suryadi bin } \\
\text { Maddin Rangkuti }\end{array}$ \\
\hline Umur & 17 tahun & 17 tahun & 16 tahun \\
\hline
\end{tabular}

${ }^{17)}$ Peneliti, Wawancara, dengan Hakim Pengadilan Negeri Jakarta Barat, (Jakarta: Pengadilan Negeri Jakarta Barat, 29 November 2018). 


\begin{tabular}{|c|c|c|c|}
\hline $\begin{array}{l}\text { Pasa1 yang } \\
\text { dilanggar }\end{array}$ & $\begin{array}{l}\text { Pasa1 } 112 \text { Ayat } \\
\text { (1) UU } \\
\text { Narkotika }\end{array}$ & $\begin{array}{l}\text { Pasal } 112 \text { Ayat (1) } \\
\text { jo. Pasa1 } 132 \text { Ayat } \\
\text { (1) UU Narkotika }\end{array}$ & $\begin{array}{l}\text { Pasa1 } 112 \text { Ayat (1) } \\
\text { UU Narkotika }\end{array}$ \\
\hline $\begin{array}{l}\text { Jenis } \\
\text { Narkoba }\end{array}$ & Sabu & $\begin{array}{l}\text { Sabu } \\
\text { (Metamfetamina) }\end{array}$ & $\begin{array}{l}\text { Sabu } \\
\text { (Metamfetamina) }\end{array}$ \\
\hline $\begin{array}{l}\text { Gol. } \\
\text { Narkotika }\end{array}$ & Narkotika Gol. 1 & Narkotika Gol. 1 & Narkotika Gol. 1 \\
\hline Berat & 1,59 gram & 0,1317 gram & 0,0394 gram \\
\hline Diversi & Diupayakan & Tidak diupayakan & Tidak diupayakan \\
\hline $\begin{array}{l}\text { Hal-hal } \\
\text { memberatkan }\end{array}$ & - & $\begin{array}{l}\text { Perbuatan Anak } \\
\text { tersebut } \\
\text { bertentangan } \\
\text { dengan program } \\
\text { pemerintah dalam } \\
\text { upaya } \\
\text { pemberantasan } \\
\text { Narkotika }\end{array}$ & $\begin{array}{l}\text { Perbuatan Anak } \\
\text { tersebut tidak } \\
\text { mendukung } \\
\text { program } \\
\text { pemerintah dalam } \\
\text { upaya } \\
\text { pemberantasan } \\
\text { tindak pidana } \\
\text { narkotika } \\
\end{array}$ \\
\hline $\begin{array}{l}\text { Hal-hal } \\
\text { meringankan }\end{array}$ & - & $\begin{array}{l}\text { Anak menyesal, } \\
\text { mengakui } \\
\text { perbuatannya dan } \\
\text { berjanji tidak akan } \\
\text { mengulangi } \\
\text { perbuatannya }\end{array}$ & $\begin{array}{l}\text { Anak belum pernah } \\
\text { dihukum, Anak } \\
\text { sopan di } \\
\text { persidangan, Anak } \\
\text { mengakui dan } \\
\text { menyesali } \\
\text { perbuatannya dan } \\
\text { berjanji tidak akan } \\
\text { mengulanginya, } \\
\text { Anak masih duduk } \\
\text { dibangku sekolah } \\
\text { dan berjanji tidak } \\
\text { akan } \\
\text { mengulanginya } \\
\text { lagi. }\end{array}$ \\
\hline
\end{tabular}




\begin{tabular}{|c|c|c|c|}
\hline Amar & $\begin{array}{l}\text { Memerintahkan } \\
\text { para pihak untuk } \\
\text { melaksanakan } \\
\text { kesepakatan } \\
\text { Diversi } \\
\text { (menjalani } \\
\text { Rehabilitasi } \\
\text { Sosial di ANKN } \\
\text { (Anak Nakal dan } \\
\text { Korban } \\
\text { Narkotika) } \\
\text { selama } 4 \text { (empat) } \\
\text { bulan) }\end{array}$ & $\begin{array}{l}\text { Menjatuhkan } \\
\text { pidana pembinaan } \\
\text { pada Lembaga } \\
\text { Pembinaan Khusus } \\
\text { Anak (LPKA) } \\
\text { Salemba dengan } \\
\text { penjara selam } 1 \\
\text { (satu) tahun dan } \\
\text { pidana tambahan } \\
\text { pelatihan kerja } \\
\text { selama 1 (satu) } \\
\text { bulan di BAPAS } \\
\text { Kelas I Jakarta } \\
\text { Barat }\end{array}$ & $\begin{array}{l}\text { Menjatuhkan } \\
\text { pidana penjara } \\
\text { selama } 2 \text { (dua) } \\
\text { tahun dan denda } \\
\text { sebesar Rp } \\
800.000 .000,- \\
\text { (delapan ratus juta } \\
\text { rupiah), apabila } \\
\text { denda tersebut } \\
\text { tidak dibayar } \\
\text { diganti dengan } \\
\text { pidana penjara } \\
\text { selama 1 (satu) } \\
\text { bulan }\end{array}$ \\
\hline
\end{tabular}

Setelah Penulis membandingkan ketiga kasus yang diteliti, terlihat jelas bahwa terdapat kejanggalan. Dari segi berat narkotika, beratnya berturut-turut (tinggi ke rendah) Penetapan Nomor 111/Pid.Sus-Anak/2014/PN.Jkt.Brt 1,59 gram, Putusan Nomor 47/Pid.Sus-Anak/2017/PN.Jkt.Brt 0,1317 gram, dan Putusan Nomor 53/Pid.Sus-Anak/2017/PN.Jkt.Brt 0,0394 gram. Ketiganya merupakan penyalahguna, dua diantaranya menggunakan narkotika bukan dari ide sendiri melainkan karena diajak. Namun amarnya berturut-turut (tinggi ke rendah) Putusan 53/Pid.Sus-Anak/2017/PN.Jkt.Brt penjara 2 (dua) tahun, Putusan Nomor 47/Pid.Sus-Anak/2017/PN.Jkt.Brt penjara 1 (satu) tahun dan pelatihan kerja 1 (satu bulan), dan Penetapan Nomor 111/Pid.SusAnak/2014/PN.Jkt.Brt rehabilitasi sosial di ANKN (Anak Nakal dan Korban Narkotika) selama 4 (empat) bulan.

Walaupun Penulis setuju dengan pendapat Sarjiman yang mengatakan bahwa setiap kasus itu bersifat kasuistis, sehingga perkara yang satu tidak bisa secara serta merta disamakan dengan perkara yang lain, namun setelah melakukan penelitian dan perbandingan, terlihat jelas bahwa dalam hal ini 
kasus-kasus yang diteliti memiliki fakta-fakta hukum serupa, sehingga perbedaan penerapan hukum yang begitu signifikan terasa seakan-akan mengabaikan prinsip dasar penyelenggaraan perlindungan anak di Indonesia yaitu prinsip kepentingan terbaik bagi anak. Dalam menjatuhkan pidana bagi anak tidak bisa semata-mata utnuk pembalasan atas perbuatan pidana yang telah dilakukan oleh anak, tetapi juga harus benar-benar mempertimbangkan kepentingan terbaik bagi anak.

Hal ini sesuai dengan teori gabungan (teori pemidanaan) yang dikemukakan oleh Zevenbergen bahwa makna tiap pidana adalah pembalasan, tetapi tiap pidana itu bermaksud melindungi ketertiban hukum, mengembalikan hormat (respect) kepada hukum dan pemerintah. Oleh karena itu pada hakikatnya pidana itu hanya suatu suatu jalan terakhir yang boleh dipakai jika tidak ada lagi jalan lain (ultimum remedium). ${ }^{18)}$

Penulis berpendapat bahwa dalam kasus anak pada umumnya dan anak pelaku tindak pidana penyalahgunaan narkotika pada khusunya, hak-hak anak harus dipenuhi. Dimulai dari hak untuk diupayakan diversi, hak anak korban penyalahguna narkotika untuk direhabilitasi, dan hak atas penghindaran dari penangkapan, penahanan atau penjara, kecuali sebagai upaya terakhir dan dalam waktu yang paling singkat.

\section{PENUTUP}

\section{A. Kesimpulan}

Penyalahguna merupakan seseorang yang memakai narkoba tanpa hak atau melawan hukum. Anak yang melakukan tindak pidana penyalahgunaan narkotika, merupakan pelaku sekaligus korban. Dalam rangka melindungi ketertiban hukum dan mengembalikan rasa hormat kepada hukum, apabila seorang anak melakukan suatu perbuatan yang melanggar hukum, dalam hal

\footnotetext{
${ }^{18)}$ Tolib Setiady, Pokok-Pokok Hukum Penitensier Indonesia, (Bandung: Alfabeta, 2010), 53.
} 
ini tindak pidana penyalahgunaan narkotika, anak tetap harus mengikuti proses penyelesaian perkara sebagaimana diatur dalam UU S.P.P.A..

Namun karena UU S.P.P.A. menggunakan pendekatan restorative justice dalam menyelesaikan suatu perkara, konsep diversi hadir untuk menghindarkan anak dari stigma negatif peradilan. Dalam penelitian ini, Jerrico Rizky Anugrah, Endeng Rafly dan Ahmad Suryadi merupakan anak pelaku tindak pidana penyalahgunaan narkotika. Namun diantara mereka, ketiganya mendapat penetapan / putusan berbeda.

Berdasarkan penelitian yang telah dilakukan, Penulis menyimpulkan bahwa perbedaan penetapan pengadilan terhadap anak pelaku tindak pidana penyalahgunaan narkotika dalam Penetapan Pengadilan Negeri Surabaya Nomor 111 / Pid.Sus-Anak / 2014 / PN.Sby, Putusan Pengadilan Negeri Jakarta Barat Nomor 47/Pid.Sus-Anak/2017/PN.Jkt.Brt dan Putusan Pengadilan Negeri Jakarta Barat Nomor 53/Pid.Sus-Anak/2017/PN.Jkt.Brt disebabkan oleh hal-hal sebagai berikut:

1. Bahwa adanya inkonsistensi antara peraturan perundang-undangan yang mengatur mengenai diversi. Perbenturan antara peraturan perundangundangan yaitu UU S.P.P.A., Perma 4/2014, dan PP 65/2015 tersebut menimbulkan perdebatan diantara aparat-aparat penegak hukum mengenai peraturan mana yang dapat diterapkan dalam praktek. Inkonsistensi dalam peraturan juga menimbulkan perbedaan penafsiran dari beda pihak. Sehingga dalam praktek, ditemukan bahwa dalam tindak pidana yang sama ada yang diupayakan diversi, ada yang tidak;

2. Bahwa hakim memiliki kebebasan dalam memutus perkara. Hakim di Indonesia dalam memutus suatu perkara tidak ada kewajiban atau dengan kata lain tidak terikat untuk mengikuti putusan terdahulu. Setiap hakim memiliki keyakinan sendiri dan memiliki kemerdekaan untuk memutus suatu perkara; dan 
3. Bahwa dalam prakteknya, peraturan tidak selalu dijalankan karena setiap instansi mempunyai penafsiran tersendiri terhadap hukum yang mereka terapkan dan bagaimana cara mereka menerapkan hukum tersebut.

\section{B. Saran}

Anak perlu dihindarkan dan dijauhkan dari perbuatan pidana yang dapat mempengaruhi perkembangan fisik, mental dan rohaninya secara negatif. Oleh karena itu walaupun anak melakukan penyimpangan atau pelanggaran hukum, negara tetap harus memberi perlindungan terhadapnya. Perlindungan hukum yang diatur dalam UU P.A., terutama dalam hal ini mengenai perlindungan khusus bagi anak yang berhadapan dengan hukum harus diterapkan secara mutlak bagi anak yang berhadapan dengan hukum.

Dalam hal anak merupakan pelaku sekaligus korban penyalahgunaan narkotika, anak wajib direhabilitasi baik medis maupun sosial, dan dihindarkan dari pengangkapan, penahanan atau penjara kecuali sebagai upaya terakhir dan dalam waktu yang sesingkat-singkatnya. Bagi anak pelaku tindak pidana penyalahgunaan narkotika, baiknya didakwa dengan Pasa1 127 UU Narkotika alih-alih Pasal 112 Ayat (1) UU Narkotika karena memiliki ancaman pidana yang lebih rendah dan hak atas rehabilitasi diatur secara khusus bagi penyalahguna sebagaimana dimaksud dalam Pasa1 127 UU Narkotika. Selain itu, dengan ancaman pidana 4 (empat) tahun, maka tidak akan ada perbedaan penafsiran hukum dan sudah pasti memenuhi syarat diversi.

Selain itu, dibutuhkan sinergi antara aparat-aparat penegak hukum anak agar terjadi keterpaduan dalam upaya penegakan hukum dalam peradilan pidana anak.

\section{DAFTAR PUSTAKA}

\section{A. Buku}

Djamil, M. Nasir. Anak Bukan Untuk Dihukum. Jakarta: Sinar Grafika, 2013. 
Marlina. Pengantar Konsep Diversi dan Restorative Justice. Medan: USU Press, 2010. . Peradilan Pidana Anak Di Indonesia: Pengembangan Konsep Diversi dan Restorative Justice. Bandung: Refika Aditama, 2012.

Sambas, Nandang. Peradilan Pidana Anak di Indonesia dan Instrumen Internasional Perlindungan Anak serta Penerapannya. Yogyakarta: Graha Ilmu, 2013.

Setiady, Tolib. Pokok-Pokok Hukum Penitensier Indonesia. Bandung: Alfabeta, 2010.

Zehr, Howard dan Ali Gohar. The Little Book of Restorative Justice. PA: Good Books, 2002.

\section{B. Artikel Jurnal Cetak}

Prayitno, Kuat Puji. "Restorative Justice untuk Peradilan di Indonesia (Perspektif Yuridis Filosofis dalam Penegakan Hukum In Concreto)", Jurnal Dinamika Hukum. Volume 12, Nomor 3 (September 2012): 407-420.

Suhadi. "Urgensi Undang-Undang Sistem Peradilan Pidana Anak". Jurnal Hukum Khaira Ummah. Volume 12, Nomor 4 (Desember 2017): 853-861.

Yunus, Yutirsa. "Analisis Konsep Restorative Justice Melalui Sistem Diversi dalam Sistem Peradilan Pidana Anak di Indonesia”. Jurnal RechtsVinding. Volume 2, Nomor 2 (Agustus 2013): 231-245.

\section{Website}

Anonim. "Pengertian Anak". https://kbbi.web.id/anak. Diakses tanggal 25 Mei 2018. 